\section{Cross-Cultural Communication: Linguistic and Cultural Dimensions - Implications for the Language Classroom}

\author{
Gloria Poedjosoedarmo \\ SEAMEO Regional Language Centre \\ Singapore
}

\begin{abstract}
Differences in cultural perspectives can be one of several possible causes for communication breakdowns in cross-cultural communication. This paper will attempt to classify possible causes for communication breakdown and explore sorts of knowledge and skills students need to avoid these situations, as well as classroom activities that can develop the needed knowledge and skills.
\end{abstract}

Key words: cross-cultural communication, avoiding communication breakdown

Not long ago a young woman - Chinese Singaporean, but of the languages in her repertoire, she is probably most proficient in English - asked me, "How do you say 'busybody' in Indonesian or Javanese?" I thought for a second or two, but no word in either language suggested itself to me. The only words that I could think of that were remotely related were the Javanese words crewet or criwis. But these mean "talkative" - usually implying the "giving" of information and not usually referring to asking of personal questions.

Determined to respond to the question, I tried to imagine a situation where a busybody was actually being a busy-body and tried to imagine what comments an Indonesian or Javanese speaker would make. But that didn"t work either. The problem had to do with cultural differences in evaluation of activities involved in being a busybody.
In English-speaking cultures, to ask another person many personal questions is regarded as being "nosy" and a "nosy" person is a busybody. This is considered a bad thing. In Indonesian and especially Javanese society on the other hand, to ask another person questions about themselves is regarded as showing interest in the other person, and this is thought to be a good thing.

Differences in cultural perspectives can be one of several possible causes for communication breakdowns in cross-cultural communication. This paper will attempt to classify possible causes for communication breakdown and explore sorts of knowledge and skills students need to avoid these situations, as well as classroom activities that can develop the needed knowledge and skills.

\section{CAUSES FOR COMMUNICATION BREAKDOWNS}

I would like to propose a classification of causes of communication breakdown into three large groups: cultural, textual and structural. We will now examine each of them in turn.

\section{Cultural Causes of Communication Breakdown}

We looked at one example above of a communication problem resulting from differences in attitudes towards and evaluation of a set of activities i.e. being a "busybody". Cultural causes of communication breakdowns might also involve differences in systems for breaking up the world and classifying and labelling entities and ideas in it. For example, though in European languages, including English, sheep and goats are different animals with different names, in many Asian languages a single word is used for both. For example, kambing in Indonesian/Malay, wedus in Javanese, and yáng in Mandarin can all refer to either.

Another example - growth on the outer surface of the skin of birds and mammals is called by more than one name in both Indonesian/Malay and in English but the categories are only partially overlapping. In English, regardless of where the growth is, it is called hair if it is on a human, while mammals, other than humans, have fur and birds have feathers. In Indonesian/Malay, one word - bulu - refers to feathers on birds, fur on mammals (other than humans) and hair on humans everywhere except on the head. 
Hair on the head is called rambut.

These are just a few examples of differences between languages in classification systems. An example of problems this latter difference might cause in communication has been reported from countries like Malaysia (where some schools use English as the medium of instruction) and the Philippines (where most school subjects are taught in English and where the local languages treat growth on body surfaces semantically like Malay/Indonesian). Problems here arise in biology classes when teachers are trying to explain the basis for the classification system and make statements in English like, "Birds have feathers but mammals have fur." The children, however, will mentally translate this as, "Kalau burung, ada bulu, tetapi(?), kalau mamalia, [juga?] ada bulu." Naturally, the children will be confused.

\section{Textual Causes of Communication Breakdown}

We will now look at textual causes of communication breakdown. This includes features of discourse structure, which may include:

- differences in classification and features of particular text types,

- patterns of organization of ideas in texts with a given purpose,

- constraints on what is implied, what must be made explicit, and what is redundant.

Let's look at some examples.

\section{Differences in Classification and Features of Particular Text Types}

For English, different writers have proposed somewhat different classifications of text types or genres (a classification based on communicative purpose of the text). The classification adopted by the Singapore Ministry of Education in the 2001 Syllabus, which is parallel in many respects to the one that has been in use in Australian schools for more than a decade, recognises six main text types. The list below represents the common features of the two systems (Australian and Singaporean) with slight modification of some of the labels for the sake of clarity:
- Narratives - tell a story, usually in order to entertain, but sometimes with a moral lesson

- Recounts - tell about something that happened

- Reports - classify and describe the characteristics of some class of entities

- Instructions - present the steps required to do or make something in sequential order so that someone else can carry them out

- Explanation - tell how or why something works the way it does so that someone else will understand the process

- Argument - presents a particular belief or viewpoint so as to convince listeners or readers that it is correct.

Each of the English text types is characterised by certain grammatical features. For example, narratives (fictional stories) and recounts (true stories) are generally in the past tense. Reports contain many equational sentences indicating the class to which an entity belongs or characteristics it possesses. Reports tend to be in the present tense unless they are describing something that existed in the past but no longer does. Instructions and explanations both normally contain lists of sequenced steps, but instructions contain verbs in the imperative while explanations are often in the passive. Arguments contain many modals, conditional statements and rhetorical questions.

Of the English text types listed above, instructions and explanations may not have distinct equivalents in Indonesian if the process described is one that can be carried out by humans. Take, for example, the following excerpt from a description in Indonesian of batik-making:

Anglo dan wajan berisi "malam" harus sudah siap untuk mulai membatik.

Malam harus sempurna cairnya supaya lancar keluanya melalui cucuk canting.

Api dalam anglo harus dijaga tetap membara, tetapi tidak boleh menyala, karena berbahaya kalau menjilat malam dalam wajan.

Mori yang sudah dipersiapkan harus telah berada di atas gawangan. 
Cara memegang canting berbeda dengan cara memegang pensil, karena tangkai canting tetap horizontal.

Dengan canting itu malam mendidih dalam wajan diciduk.

Sebelum dibatikkan canting ditiup lebih dahulu supaya tidak menetes sebelum ujung canting ditempelkan pada mori.

If we were asked to translate this text, we need to determine first whether it is intended as instructions or an explanation - that is, does the author expect the reader to want to follow instructions so as to be able to make batik by him or herself, or does the reader simply want to understand how the process works? As this passage comes from a book that is intended to be informative and appealing to tourists, the translation should probably be as an explanation. However, this segment could also be translated as instructions. Compare the two English texts below:

\section{Instructions}

Prepare the stove and small wok filled with melted wax before beginning the batik process.

Be sure that the wax is thoroughly dissolved so that it can flow smoothly through the spout of the canting.

Be sure that the fire from the stove remains burning but don't allow it to ignite to the point that it licks the wax in the wok, as this would be dangerous.

The prepared cloth should already be hanging on the frame.

The way you hold a canting is different from the way you hold a pencil-you must keep the canting in a horizontal position.

Use the canting to scoop out some of the melted wax from the wok.

Before beginning to batik, blow on the canting so that the wax will not drip before the spout is placed on the cloth.

\section{Explanation}

A stove and small wok filled with melted wax are prepared before the batik-making process begins.

The wax must be thoroughly dissolved so that it can flow smoothly through the spout of the canting.
The fire from the stove must remain burning but it should not be allowed to ignite to the point that it licks the wax in the wok, as this would be dangerous.

The prepared cloth should already be hanging on the frame.

The way the canting is held is different from the way a pencil is held - the canting must always remain in a horizontal position.

The canting is then used to scoop out some melted wax from the wok.

Before beginning to batik, the batik-maker blows on the canting so that the wax will not drip before the spout is applied to the cloth.

To return to the problem of cross-cultural misunderstanding, the purpose of a text is usually clear from the surrounding context, but one can imagine a situation in which a student, still grappling with English, is given instructions which he interprets as an explanation. In other words rather than "Do this," he thinks he is being told "This is the way it works," and as a result he may simply nod to show he understands and fail to carry out the instructions.

\section{Patterns of Organization of Ideas in Texts with a Given Purpose}

There are different patterns of organising ideas within a text. Most text types have characteristic patterns. For example, in English, narratives and recounts usually use chronological order. Reports often begin with general statements and proceed to more specific ones. In describing something, they may either begin with external features and proceed to internal ones or vice versa, depending on the nature of the entity they are describing and on the assumed background knowledge and point of view of the audience. Instructions and explanations tend to be sequenced according to the steps in the process they describe. Arguments usually begin by stating a position and then present a series of reasons for taking this position. The conclusion usually summarises the argument and restates the initial position. Another possible pattern of organisation for an argument is to begin by presenting a view opposed to the writer or speaker's position and then present a series of arguments against this view. Politicians often use this structure. 
Sometimes the usual pattern for organising ideas within a particular type of text in one language may not apply in another language, or the other language may have additional alternatives that are not found in the first language. As an example of this, a number of years ago the National Institute of Education in Singapore held a Seminar on Malay poetry and other literature. In a brochure advertising the event, which was printed in both English and Malay, a brief summary of the life and work of one of the guest writers was given. The English summary was in chronological order, as would normally be expected for this text type - a recount. The Malay version, on the other hand, had organised the information according to important themes that ran through the life and work of this author. This pattern of organisation worked very well in Malay but if translated into English, the text would appear "incoherent".

\section{Constraints on What is Implied, What Must be Made Explicit, and What is
Redundant}

One of the most onerous tasks for English language lecturers in countries where English is not a first language is reading, commenting on and marking the academic writing of students - whether assignments or exams. This is not really because of the grammatical errors - missing $s$ 's or superfluous articles don't really interfere very much with communication. It is because the text is invariably difficult to read - one can't easily determine the relationship between one sentence and the next and between one paragraph and the next. The logical structure is a mystery!

This may sound initially like the same thing as that discussed in the previous section. However, the previous section was about ordering ideas. We are now talking about selecting ideas - what to say and what not to say.

In fairness to the students, especially ones for whom English is a foreign language, what they are trying to say probably does represent an appropriate structure in their own language. However, languages also differ in terms of what we need to say and what there is no need to say because it is implied in a given text type and form. As an example of this, in English, the Acknowledgements at the beginning of a thesis, dissertation or research report for publication follow a rather stylized and formulaic pattern. They include mention of all academic staff and others who in some official or per-
haps semi-official manner helped the student or researcher to complete the project. The author may mention one or two family members who were particularly helpful, but this should not be a long list, and normally friends are not mentioned unless, again, one or two close friends went out of their way to help. But, sad as it may seem, it is not part of the formula to thank God.

As an example of things that must be said, in an academic paper, again, references must be complete and accurate. Phrases, which may be common in less formal styles of writing, even in English, such as, "As we all know. . " are not permitted in academic writing in English. A reference must be given to the source of the information cited.

\section{Structural Causes of Communication Breakdown}

"Structural causes of miscommunication" here refers to the usual problems that we as teachers tend to focus on - grammatical errors such as verb forms, marking of plurality, use of articles, etc., as well as pronunciation problems, especially confusing sounds. Annoying as these may be, they are actually infrequently the cause of true miscommunication.

If I had to choose the one structural problem which I believe most frequently results in misunderstanding, I'd probably say that it's stress placement. Why do I say this? The placement of what phoneticians call tonic stress indicates that the lexical item containing this stress is the most important bit of new information in the sentence. However, one frequently hears untrained speakers or people reading a text on an unfamiliar topic placing the stress on "old" information. The effect of this in speech is to throw the listener off, as he or she tries to identify something new about this item, and as a result, misșes the next part of the utterance.

Placement of stress on the wrong syllable of a word can also result in misunderstanding as the listener tries to think of a word with the stress pattern heard that might have been intended. Some documented examples of this are talking to themselves heard as talking to damsels (because stress was placed on the first rather than second syllable of the word), and He's very mature heard as He's very macho (again, because stress was placed on the first rather than second syllable of the word). 


\section{KNOWLEDGE AND SKILLS STUDENTS NEED TO REDUCE OR AVOID COMMUNICATION BREAKDOWN AND CLASSROOM ACTIVITIES THAT CAN DEVELOP THE NEEDED KNOWLEDGE AND SKILLS}

\section{Cultural Causes of Communication Breakdown}

When learning a new language, especially if the student is planning to interact with other people who use it as a first or dominant language, it is important to be aware of attitudes and values of those people that might differ from one's own in order to avoid communication breakdown and possibly misunderstandings. One of the roles of a teacher is to provide this knowledge, where relevant, perhaps through "pre-teaching" activities at the beginning of a relevant lesson.

Sometimes cultural concepts and semantic categories can best be taught as part of vocabulary. The examples given earlier of cross-cultural communication problems were all associated with vocabulary items - both the ones related to values (busybody, nosy) and the ones relating to a classification system (hair, fur, feathers). The teaching of such vocabulary, though, must make the meaning clear. Translation clearly would not work. For the first two concepts, a film clip, cartoon, or anecdote involving busy-bodies behaving in an obviously offensive manner might get the idea across. Here is an example of an anecdote about Dante, a $13^{\text {th }}$ century Italian poet, taken from a website that contains a collection of anecdotes:

\section{Busybody}

Dante was once so deeply immersed in meditation during a church service that he neglected to kneel during the holy sacrament. When his enemies hastened to the bishop to demand that he be punished, Dante was summoned to explain himself.

"If," he wryly observed, "those who accuse me had had their eyes and minds on God, as I did, they too would have failed to notice events around them, and most certainly would not have noticed what I was doing."

Alighieri, Dante (1265-1321) Italian poet, leader of the Italian literary renaissance [noted for such works as The Divine Comedy - his visionary pro- gress through Hell and Purgatory (escorted by Virgil) and paradise (guided by his love, Beatrice) - (completed 1321) and La vita nuova (c. 1292), as well as his critical treatises on Italian as a literary language]

\section{[Sources: C. Speroni, Wit and Wisdom of the Italian Renaissance]}

\section{(http://www.anecdotage.com/index.php?aid=9966)}

Sometimes a quotation that clearly gives the context can help students understand the meaning:

"But let none of you suffer as a murderer, or as a thief, or as an evildoer, or as a busybody in other men's matters."

$$
\text { King James' Version of the Bible: } 1 \text { Peter 4:15 }
$$

For the classification of external growth on the body, mentioned in the second example above, pictures might be used together with a chart (Figure 1).

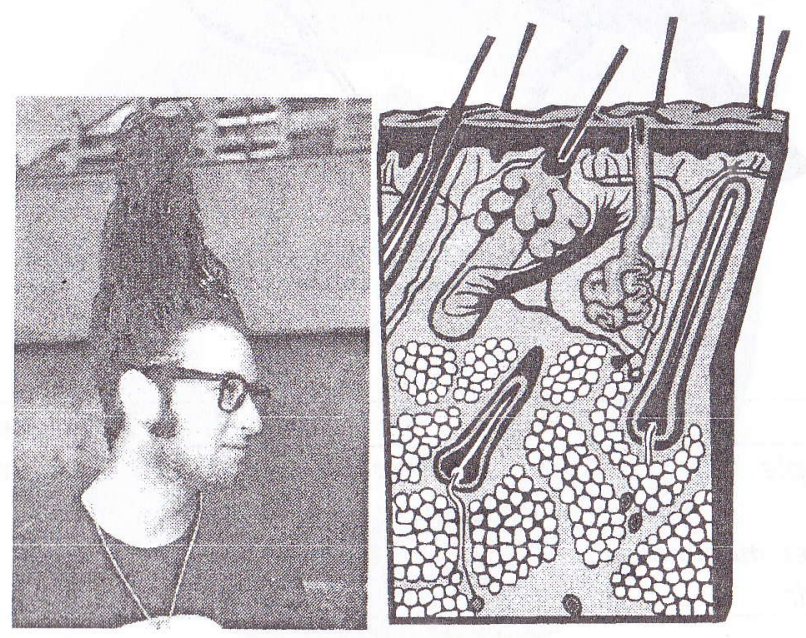

People have hair. 


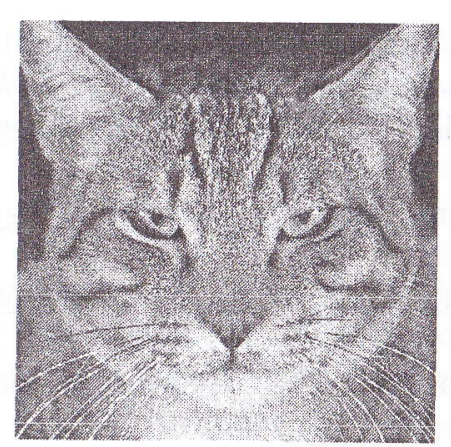

Other mammals have fur.

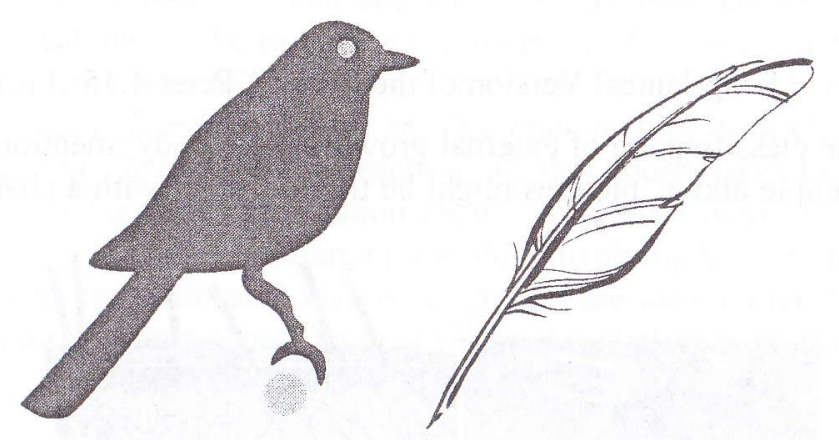

Birds have feathers

Chart:

\begin{tabular}{lccc}
\hline & & English & Indonesian \\
\hline People & on head & Hair & Rambut \\
& elsewhere & Hair & Bulu \\
Other mammals & & Fur & Bulu \\
Birds & & Feathers & Bulu \\
\hline
\end{tabular}

Figure 1. Pictures and a Chart

\section{Textual Causes of Communication Breakdown}

We divided textual causes of communication breakdown into three subcategories:

- differences in classification and features of particular text types,

- patterns of organization of ideas in texts with a given purpose.

- constraints on what is implied, what must be made explicit, and what is redundant.

For all of these potential problems, the best solution is to expose students to a large variety of texts and spend much more time on understanding the organisation, structure and purpose of the texts than on analyzing minute grammatical features in isolation. Derewianka (1990) describes a procedure for teaching reading and writing of various text types in context. She calls this the curriculum cycle. It is represented by a diagram (Figure 2).

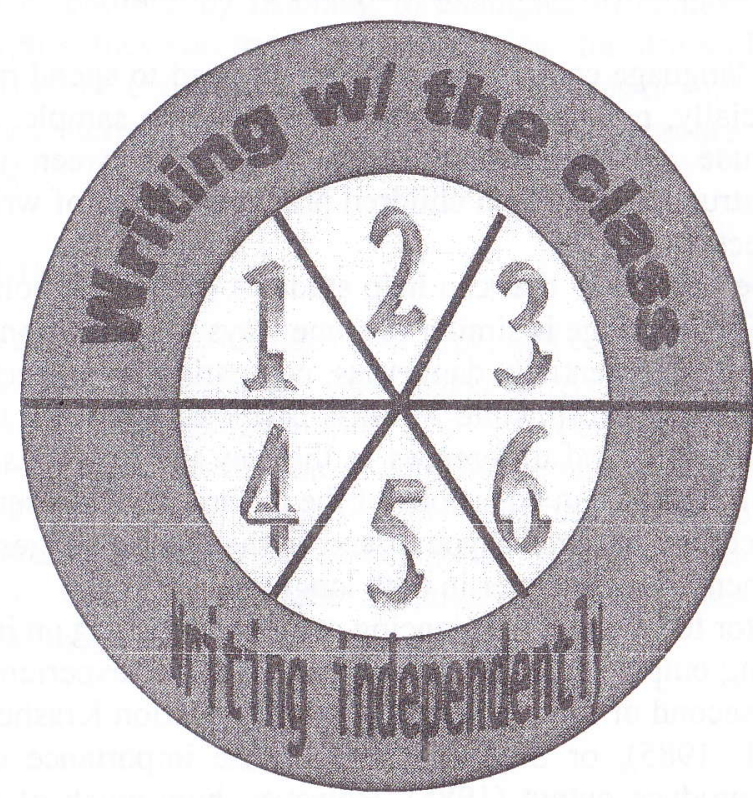

Figure 2. The Curriculum Cycle 
The numbers represent the following steps:

1. Modelling the genre: in this phase the teacher introduces an example of a text in the genre the children will learn to write and the children analyse it with the help of the teacher.

2. Building knowledge of the field: the class goes to the library or explores the internet or takes a field trip to get information on the topic they will write about

3. Joint construction: students suggest ideas and the teacher shapes them into appropriate language, writing on a board or a computer projected on a screen so children can observe the process

4. Building knowledge of a similar field: students go to the library or search the internet or the class may take another field trip to build up knowledge of a similar field

5. Independent construction: students draft, peer or teacher conference, and revise

6. Students edit and publish their finished piece of writing.

In a second language context, students might need to spend more time on step (1) especially, perhaps looking at more than one sample. It is also possible to include an intermediate series of steps between joint and independent construction, in which children produce a piece of writing as a group-work project.

Another type of activity that can help students master the composition of texts in a foreign language is similar in some ways to translation. Though translation of words is potentially dangerous, comparing equivalent texts in two languages can be a worthwhile activity. Students can work in groups and discover similarities and differences in the way the two texts are constructed. This will make them conscious of the differences between the patterns for constructing a particular type of text in the two languages and will ultimately help them to write better in both languages.

Another factor to consider is balancing activities focusing on input with activities requiring output. Probably nobody who has had experience teaching English as a second or foreign language would question Krashen's input hypothesis (1981, 1985), or Swain's stress on the importance of giving opportunities to produce output (1985). However, how much of each and when are important questions to consider. Input clearly has to come first and it should be in adequate quantity for students not only to "get the gist" but to should be in adequate quantity for students not only to "get the gist" but to fully understand how the texts are organised to convey the message. If output is then required of them in the same genre on a similar topic, they will have the framework to produce a coherent text. Requiring students to produce output before this point is bound to result in their looking up words in dictionaries and stringing them together in very un-English patterns.

\section{Structural Causes of Communication Breakdown}

As mentioned earlier, structural problems are perhaps the least frequently responsible for serious communication breakdown, though pronunciation problems can sometimes cause confusion, especially, though one may not expect it to be important - when sentence stress placement is inappropriate.

Activities to raise awareness and practice using appropriate stress placement (as well as other pronunciation features) can include letting students discover patterns by listening to examples in context and repeating them. From this, they can try to discover "rules" for stress placement. This can be followed by choral readings of familiar stories or other texts to practise the same patterns. Examples and activities of this sort are found in Poedjosoedarmo (2003).

\section{CONCLUDING NOTES}

Language, of course, changes over time, and contact between languages and varieties is one reason for these changes. As English is increasingly adopted as a second language in more and more parts of the world, as it becomes the medium of instruction in schools in increasingly more locations (note, for example, the recent decision in Malaysia to return to using English for instruction in science and mathematics), yet more local varieties are bound to arise. As this happens the question of "which model to teach?" becomes increasingly complex. 
Jenkins (2000), has argued that aiming for a "native speaker" variety is unrealistic and, anyway, probably more communication in English these days takes place between non-native speakers than between a non-native and native speaker. Therefore, she says, in teaching or learning English, we should aim for "international intelligibility" rather than for the accent of a particular English-speaking country or region.

In line with this suggestion, the Ministry of Education in Singapore, which in previous decades had advocated teaching British RP pronunciation, states in the 2001 English Language Syllabus only that the English of students should be "internationally intelligible". Similarly, while the media in Singapore had previously advocated British RP accents for their announcers, one now finds that news readers seem to appear in pairs of one woman with a British-like accent and one man with an American-like accent. In advertisements on Singapore radio stations, one also increasingly hears Australian accents.

But pronunciation, as we've said, is probably not the most likely factor to cause serious communication breakdowns. More frequently the problem has to do with cultural constraints on what one should say or do, or on patterns for organizing ideas in a text with a given purpose. Will these features of language also blend and merge as cross-national and cross-cultural interaction increases?

Perhaps Singapore, being a multi-ethnic, multi-lingual society with English as the medium of communication in schools, can represent a sort of window into the future in this respect. We do indeed find that the English of Singaporeans includes very few examples of things that speakers of English in other places do not also say. Spoken and written texts created by Singaporeans in English seem almost never to deviate so far from standard patterns of discourse organisation in other places, that they cannot be interpreted.

On the flip side, though, one hears an increasing number of young Singaporeans confessing that they cannot speak their "mother tongue". Is Singapore becoming a monolingual English-speaking society? This is surely not something that is wanted by other countries in the region, especially Indonesia, with so many languages and cultures having such long and rich histories.
In conclusion then, cross-cultural communication should remain cross cultural. The teaching of English should include developing another cultural perspective but never replacing one's own. Children should learn how English-speaking people think and organise ideas so that they can communicate effectively with people from other places. However, at the same time they should preserve a firm control of indigenous patterns for organising texts in their own languages. And it is up to us as teachers to see that this happens.

\section{REFERENCES}

Derewianka, B. 1990. Exploring How Texts Work. Rozelle, N.S.W.: Primary English Teaching Association.

Jenkins, J. 2000. The Phonology of English as an International Language. Oxford: Oxford University Press.

Krashen, S. 1981. Second Language Acquisition and Second Language Learning. New York: Prentice-Hall.

Krashen, S. 1985. The Input Hypothesis: Issues and Implications. Beverly Hills, CA: Laredo.

Poedjosoedarmo, G. 2003. Teaching Pronunciation: Why, What, When, and How. Singapore: SEAMEO RELC Portfolio Series 9.

Singapore Ministry of Education. 2001. English Language Syllabus 2001 for Primary and Secondary Schools. Singapore: Curriculum Planning and Development Division, Ministry of Education.

Swain, M. 1985. "Communicative Competence: Some Roles of Comprehensible Input and Comprehensible Output in its Development." In Input in Second Language Acquisition. Ed. By S. Gass and C. Madden, pp. 23556. New York: Newbury House.

The reason for the sex link is not clear. In one class for Singaporean teachers that I taught, one of the teachers, who had independently made the same observation, suggested that this was related to a perception that British English was more "proper" while American English was more "macho". 